\title{
Financial Statement Analysis of Nanjing Yinfei company based on Harvard Analytical Framework
}

\author{
Xin Li, Zhenggan Cai*, Xiaoyan Wu, Long Chen
}

\author{
School of Transportation and Vehicle Engineering, Shandong University of Technology, \\ Zibo, Shandong, 255000, China
}

*Corresponding author: Zhenggan Cai; zhenggancai@163.com

\begin{abstract}
The Harvard Analytical Framework is a financial analysis framework jointly proposed by three Harvard economists. Analysis of financial statements based on the Harvard framework not only helps to identify problems in the business process, but also to predict future growth potential. In this paper, the publicly traded company Nanjing Sonic was selected as the target company for the study. The Harvard Analytical Framework was adopted as an analytical tool to analyze the operating conditions and financial status of the target company for the years 2015-2019. A comparison with similar companies reveals the problems that exist. Finally, we forecast the future development prospects of the company.
\end{abstract}

Keywords: Harvard analytical framework; financial analysis; strategic analysis

\section{INTRODUCTION}

The Harvard Analytical Framework is a technique for analyzing financial statements. This method can be used for financial analysis, strategic analysis and development potential analysis. Through the analysis of the overall situation of the company, we can formulate long-term business objectives and future development plans [1]. It is of great significance to further expand the market and develop potential customers.

\section{COMPANY PROFILE}

Nanjing Yinfei company mainly provides intelligent logistics management solutions for the market. At present, the company has successfully undertaken tens of thousands of logistics enterprise warehousing system transformation projects. As a result, they are widely supported by companies that need a lot of storage equipment.

\section{FINANCIAL STATEMENT ANALYSIS OF NANJING YINFEI COMPANY UNDER HARVARD FRAMEWORK}

\section{Company Strategy Analysis}

The PEST (politics, economy, society, technology) analysis is used in the strategic analysis of the company, which is a common macro environment analysis technology in the economic field [2]. PEST analysis mainly includes political, economic, social and technological factors. The following is the macro environment analysis of the company from these four aspects.

\section{- Political factor}

With the development of China's market economy entering the new normal, the state has also increased its attention to enterprise financing [3]. And the corresponding policies have been formulated to deal with this problem. One of the representative policies is the judicial interpretation of warehousing contract. It provides a guarantee for the normal operation of warehousing enterprises. At the same time, an intelligent company management and registration information system has been implemented, which can ensure the normal operation of the market.

\section{- Economic factor}

In today's society, the market of e-commerce is developing rapidly. Its rise has brought new challenges to the storage of commodities. In order to realize the organic combination of sorting, storage, tally and delivery, warehousing enterprises must realize a high degree of automation. Therefore, Nanjing Yinfei company has invested a lot of money in intelligent storage, and carried out intelligent transformation for other enterprises. This comprehensive transformation provides a good platform for the efficient operation of the company.

\begin{abstract}
- Social factor
Different from before, the management concept of the company is changing. From the past comprehensive production mode to the core business development mode. Intelligent processing of those very important business models can improve the market demand of warehousing [4]. Due to frequent disasters in recent years, the status of reserves in the national economy has been improved. At present, China's logistics park has begun to take shape, which improves the potential demand for storage equipment.
\end{abstract}

\section{- Technical factors}

In recent years, the storage mode of large-scale threedimensional warehouse develops rapidly. This has promoted the sustainable development of the warehousing industry. At the same time, it can increase the normal circulation of storage equipment. In terms of technology, European and American countries are still in the lead in warehousing technology. At the same time, there are many places for us to learn. Using science and technology to establish intelligent warehouse management system is a trend that cannot be ignored. This also provides support for the healthy development of China's warehousing industry. 


\section{Company accounting analysis}

Balance sheet analysis

According to the company's annual report (2015-2019)

disclosed by Nanjing Yinfei company in Shanghai Stock

Exchange, draw the balance sheet analysis (TABLE1).
It can be seen from Table 1 that the company's total assets increased by $53.85 \%$ from $\$ 947,208,400$ in 2015 to $\$ 145,730,410$ in 2019 . Liabilities increased by $117.59 \%$ from $\$ 21,989.42$ million in 2015 to $\$ 478,446.46$ million in 2019. Owner's equity increased by $34.58 \%$ from $\$ 72,731.41$ in 2015 to $\$ 97,883.95$ million in 2019 .

TABLE 1: Trend analysis of balance sheet

\begin{tabular}{|c|c|c|c|c|c|}
\hline Project Year & 2015 & 2016 & 2017 & 2018 & 2019 \\
\hline Total current assets & $79,073.63$ & $83,087.35$ & $96,912.74$ & $102,685.02$ & $122,572.25$ \\
\hline Total non-current assets & $15,647.21$ & $18,497.21$ & $20,930.12$ & $24,759.49$ & $23,158.16$ \\
\hline Total Assets & $94,720.84$ & $101,584.56$ & $117,842.86$ & $127,444.51$ & $145,730.41$ \\
\hline Total Current Liabilities & $20,533.61$ & $19,929.43$ & $28,947.11$ & $31,990.50$ & $45,092.71$ \\
\hline Total Non-current Liabilities & $1,455.81$ & $1,740.42$ & $1,526.43$ & $1,013.31$ & $2,753.75$ \\
\hline Total liabilities & $21,989.42$ & $21,669.85$ & $30,473.54$ & $33,003.81$ & $47,846.46$ \\
\hline Total owner's equity & $72,731.41$ & $79,914.71$ & $87,369.32$ & $94,440.71$ & $97,883.95$ \\
\hline Liabilities and owners' equity & $94,720.83$ & $101,584.56$ & $117,842.86$ & $127,444.52$ & $145,730.41$ \\
\hline
\end{tabular}

As of December 31, 2019, current and non-current assets accounted for $84.11 \%$ and $15.89 \%$ of total assets, respectively. Current liabilities and non-current liabilities accounted for $94.24 \%$ and $5.76 \%$ of total liabilities. This indicates a high percentage of visible current liabilities. This is mainly because the company has no long-term borrowings. The company's assets, liabilities and owner's equity have all grown to varying degrees, indicating that the company has been in a rapid growth phase since its IPO [5].

\section{Income statement analysis}

Through the analysis of the company's profit statement in recent five years, this paper analyzes the company's profit situation. As shown in TABLE 2.

TABLE 2: Trend analysis of profit statement

\begin{tabular}{lc|c|c|c|c|c|}
\hline & Year & $\mathbf{2 0 1 5}$ & $\mathbf{2 0 1 6}$ & $\mathbf{2 0 1 7}$ & $\mathbf{2 0 1 8}$ & $\mathbf{2 0 1 9}$ \\
\cline { 3 - 7 } Project & & & & & \\
\hline Business income & $46,405.74$ & $49,018.85$ & $59,891.10$ & $68,940.83$ & $70,114.32$ \\
operating profit & $7,604.94$ & $9,371.21$ & $9,798.69$ & $10,288.83$ & $9,032.34$ \\
Total profit & $7,942.74$ & $9,634.58$ & $9,710.20$ & $10,396.99$ & $9,052.13$ \\
Net profit & $6,792.81$ & $8,185.83$ & $8,302.86$ & $9,172.27$ & $7,697.32$ \\
Net profit margin on sales (\%) & 14.63 & 19.65 & 13.86 & 13.30 & 18.61 \\
\hline
\end{tabular}

It can be seen from Table 2 that the operating revenue of Nanjing Yinfei has been on the rise in the past five years, from 46405.74 million in 2015 to 70114.32 million in 2019 , an increase of $51.09 \%$. Due to the rapid development of logistics in recent years, the demand for automated warehousing and company benefits have gradually increased. In 2019, the company's net profit decreased due to the increase of credit impairment loss and interest expense.

\section{Financial analysis of the company}

This section makes a longitudinal analysis on the solvency, operation ability and profitability of Nanjing Yinfei company based on the data in recent five years. Then, it makes a horizontal analysis with Shanghai Shicang company and Shenzhen Jintian company, which are powerful competitors in the logistics equipment industry.

\section{Solvency analysis}

- Longitudinal analysis

It can be seen from Table 3 that the current ratio reached the highest in 2016 and has been in a downward trend in the following years. Generally speaking, it shows a downward trend. The change trend of quick ratio and current ratio is the same. This change is mainly due to the company's good performance of automation integration projects in 2016, with a sharp rise in cash on hand. After that, the company increased its investment in the automation and intelligent industry, making the current liabilities increase every year, which shows that the shortterm solvency of Nanjing Yinfei is gradually weakening. The asset liability ratio and equity ratio of the company are basically the same in 2017 and 2018, which are in a stable state and have an upward trend compared with the previous two years. This shows that the long-term solvency of enterprises has declined. 
TABLE 3: Vertical analysis of solvency

\begin{tabular}{|c|c|c|c|c|c|}
\hline Project $\quad$ Year & 2015 & 2016 & 2017 & 2018 & 2019 \\
\hline Current ratio (\%) & 385.34 & 417.46 & 335.34 & 321.73 & 272.36 \\
\hline Quick ratio (\%) & 332.45 & 353.57 & 267.46 & 233.26 & 222.78 \\
\hline Asset liability ratio (\%) & 23.21 & 21.33 & 25.86 & 25.90 & 32.83 \\
\hline Equity ratio (\%) & 30.15 & 27.48 & 34.38 & 35.48 & 49.28 \\
\hline
\end{tabular}

TABLE 4: Horizontal analysis of solvency

\begin{tabular}{|c|c|c|c|}
\hline $\begin{array}{ll}\text { Project } & \text { Company } \\
\end{array}$ & Nanjing Yinfei & Shanghai Shicang & Shenzhen Jintian \\
\hline Current ratio (\%) & 272.36 & 140.35 & 154.28 \\
\hline Quick ratio (\%) & 222.78 & 73.83 & 122.58 \\
\hline Asset liability ratio (\%) & 32.83 & 67.07 & 55.21 \\
\hline Equity ratio (\%) & 49.28 & 204.58 & 123.26 \\
\hline
\end{tabular}

It can be seen from TABLE 4 that the current ratio and quick ratio of Nanjing Yinfei are higher than those of the other two companies in 2019, which shows that although the short-term debt repayment of Nanjing Yinfei has declined, it still has certain advantages compared with other companies. At the same time, the asset liability ratio is lower than that of other companies. To a certain extent, it reflects that Nanjing Yinfei has strong debt paying ability.
The company can also increase debt investment. In terms of property right ratio, Shenzhen is the most reasonable in the world today, giving full play to the financial leverage of debt. Although Nanjing Yinfei enterprise has strong long-term solvency and low risk, the corresponding remuneration is also low, so the company can appropriately increase some liabilities.

\section{Operation capability analysis}

- Longitudinal analysis

TABLE 5: Vertical analysis of operation capacity

\begin{tabular}{|l|c|c|c|c|c|}
\hline Year & $\mathbf{2 0 1 5}$ & $\mathbf{2 0 1 6}$ & $\mathbf{2 0 1 7}$ & $\mathbf{2 0 1 8}$ & $\mathbf{2 0 1 9}$ \\
\hline Project & & & & & \\
\hline Accounts receivable turnover & 2.26 & 2.87 & 3.36 & 3.08 & 2.50 \\
Inventory turnover & 3.51 & 2.58 & 2.48 & 1.94 & 1.86 \\
Turnover rate of fixed assets & 6.31 & 5.13 & 6.18 & 7.10 & 7.75 \\
Turnover of total assets & 0.61 & 0.49 & 0.54 & 0.56 & 0.51 \\
\hline
\end{tabular}

- Lateral analysis

TABLE 6: Horizontal analysis of operation capacity

\begin{tabular}{l|c|c|c|}
\hline Company & Nanjing Yinfei & Shanghai Shicang & Shenzhen Jintian \\
\hline Accounts receivable turnover & 2.50 & 2.44 & 1.48 \\
Inventory turnover & 1.86 & 2.06 & 1.97 \\
Turnover rate of fixed assets & 7.75 & 3.64 & 6.95 \\
Turnover of total assets & 0.51 & 1.01 & 0.44 \\
\hline
\end{tabular}

It can be seen from TABLE 5 that the turnover rate of accounts receivable is low and very stable, indicating that the company has more accounts receivable and long recovery period. At present, the total inventory and turnover rate of the company's goods have shown a downward trend year by year, which indicates that the products are unsalable to a certain extent. The company's products are mostly large-scale logistics transportation equipment, such as shelves, shuttle cars, etc. The turnover rate of total assets reached the highest in 2015, decreased suddenly in 2016, and recovered in the last three years. This shows that the enterprise has been operating well in recent years, but the operating condition is still poor compared with 2015. In recent years, the company has strengthened the management of the company's operation, and there is plenty of room for development.

It can be seen from Table 6 that the turnover rate of accounts receivable of Nanjing Yinfei has a slight advantage, the company's collection speed is faster, and the gap between the three companies is not very big. In terms of inventory turnover rate, they are lower than the other two companies. At that time, it is necessary for enterprises to improve sales and solve the problem of overstock. The turnover rate of total assets and fixed assets of Nanjing Yinfei are higher than those of other companies, indicating that the assets of the enterprise are highly utilized and the fixed assets are fully utilized. 


\section{Profitability analysis}

- Vertical comparison

TABLE 7: Vertical analysis of profitability

\begin{tabular}{|l|c|c|c|c|c|}
\hline Year & $\mathbf{2 0 1 5}$ & $\mathbf{2 0 1 6}$ & $\mathbf{2 0 1 7}$ & $\mathbf{2 0 1 8}$ & $\mathbf{2 0 1 9}$ \\
\hline Project & & & & & \\
\hline Gross profit margin of sales (\%) & 35.49 & 37.71 & 32.51 & 32.71 & 33.40 \\
Net profit rate of sales (\%) & 14.63 & 16.69 & 13.86 & 13.30 & 10.98 \\
Return on net assets (\%) & 11.98 & 10.81 & 10.02 & 10.24 & 8.00 \\
Net interest rate of total assets (\%) & 9.02 & 8.33 & 7.56 & 7.47 & 5.64 \\
\hline
\end{tabular}

- Lateral analysis

TABLE 8: Horizontal analysis of profitability

\begin{tabular}{lcc|c|c|}
\hline Company & Nanjing Yinfei & Shanghai Shicang & Shenzhen Jintian \\
Project & 33.4 & 24.5 & 28.95 \\
Gross profit margin of sales (\%) & 10.98 & 0.93 & 6.66 \\
Net profit rate of sales (\%) & 8.00 & 2.64 & 6.1 \\
Return on net assets (\%) & 5.64 & 0.94 & 2.93 \\
Net interest rate of total assets (\%) & & \\
\hline
\end{tabular}

It can be seen from Table 7 that the gross profit margin and net profit margin of sales of the company were the highest in 2016. In 2018, the gross profit margin of sales increased and the net profit margin of sales decreased. The main reason is the increase of financial expenses and sales expenses, and the net profit rate of sales shows a downward trend in the past three years, which indicates that the profitability of enterprises has declined, which is directly related to the backlog of products. The net interest rate of total assets has been decreasing year by year. In recent years, due to the impact of the financial crisis, the company's operation has become more difficult, the cost has increased, and the company's income has decreased.

It can be concluded from Table 8 that all the indexes of Nanjing Yinfei are higher than those of the other two companies. In general, the profitability of Nanjing Yinfei is higher than that of the other two companies.

\section{Prospect analysis of the company \\ Industry prospect analysis}

In 2019, the total amount of social logistics will continue to grow. At present, automated logistics equipment is most widely used in tobacco, medicine, e-commerce, new retail, new energy, intelligent manufacturing, cold chain, food and beverage, automobile and other industries. The main reason is that the above industries have large scale, many circulation links, complex production processes, and generally strong profitability. They have the willingness and ability to invest in automated logistics system projects, which is also an important driving force to promote the comprehensive development of the automated logistics industry market.

\section{Future risks and challenges}

- Macroeconomic cyclical risk

The structural adjustment of monetary policy in China's macroeconomic cycle and the cyclical fluctuation of the market will have a great impact on the fixed assets investment and monetary policy of some downstream customers of fixed assets companies, and then directly affect the demand of the fixed assets industry.

\section{- Risk of price fluctuation of main raw materials}

The company's products mainly steel and various steel products as the main raw materials, accounting for a relatively high proportion of the company's operating costs. At present, the company's pricing principle is to determine the company's product price according to the pricing principle of operating cost and raw material bonus. The frequent fluctuation of raw materials in the short term has a great impact on the company's cost.

\section{- Impact of epidemic situation}

In 2020, the new epidemic of coronary pneumonia has spread all over the world, and the global economy is sluggish [5]. Although the domestic epidemic has been under control, we cannot rule out the possibility of rebound, which seriously affects the establishment of downstream customers. If the foreign epidemic cannot be effectively controlled, the foreign market performance will be seriously damaged.

\section{CONCLUSION AND SUGGESTION}

In recent years, the market demand of China's logistics equipment industry continues to grow. It is expected that China's logistics equipment industry will continue to grow at a high speed in the next few years. With its own economic and technical factors, Nanjing Yinfei company is expected to tapits own potential in the case of rapid market growth. Through accounting analysis, we can conclude that the company is in the stage of rapid development, the scale is expanding, and the capital is abundant. But the capital utilization rate is low, the company has made a lot of investment, the profitability has declined, and is facing greater challenges. Through the financial analysis and the analysis with competitors, it is concluded that Nanjing Yinfei has strong long-term and shortterm debt paying comprehensive ability, but in the past two years, it has a downward trend, strong profitability, but the company's operating efficiency is low, and there is still a lot of room for development. To sum up, the logistics equipment industry has a broad prospect, the market demand is growing, and the intelligent logistics equipment is widely used. The company should seize the opportunity to meet the challenge.

Strategy: in recent years, the economic situation is complex and changeable, especially under the influence of the epidemic situation, the company's managers should carefully investigate, minimize the losses caused by the epidemic situation, and formulate reasonable development strategies according to the economic situation to deal with economic problems.

Accounting: the company's automation equipment integration system product cycle time is long, and warehousing equipment products are not suitable for turnover, easy to cause inventory backlog, affecting the company's efficiency. The company should strictly plan the project process to ensure the smooth progress of the project. 
Financial aspect: through the comparison with the competitors, we found the deficiencies in the development of Nanjing Yinfei. In view of the unreasonable phenomenon of low asset liability ratio, the company should not be too cautious, and carry out appropriate financing activities to increase the production and $\mathrm{R} \& \mathrm{D}$ of intelligent logistics equipment, make rational use of financial leverage and improve the utilization rate of funds.

Prospect: in the current situation of sustainable development of logistics industry, the company should establish logistics warehousing center to serve its own business, form joint efforts in warehousing equipment, warehousing logistics operation services and other fields, and improve the comprehensive warehousing service system. Carry out market sensitivity analysis, continue to strengthen the procurement of raw materials and cost control, and actively negotiate with downstream customers and suppliers to reduce their corresponding risks.

\section{REFERENCES}

[1] X. Li, Z. Cai, X. Wu, L. Chen. (2021). Investigation of Financial Statements Under the Framework of Harvard Analysis. International Journal of Scientific Advances, 2(1), 85-87.

[2] Z. P. Yang. (2012). Petro China financial statement analysis based on Harvard framework. Master's thesis of Jilin University.

[3] S. Z. Huang. (2007). Financial statement analysis. Beijing: China financial and Economic Publishing House, 56-60.

[4] Y. W. Fan. (2014). Research on the application of financial analysis of CTS under the Harvard Analysis Framework. Lanzhou University.

[5] R. W. Scholz, R. Czichos, P. Parycek, T. L. Lampoltshammer. (2020). Organizational vulnerability of digital threats: a first validation of an assessment method. European Journal of Operational Research, 282(2), 627-643. 